\title{
Mitochondrial gene variation in Mercenaria clam sibling species reveals a relict secondary contact zone in the western Gulf of Mexico
}

Received: 16 February 1996/Accepted: 6 April 1996

\begin{abstract}
We investigated phylogeographic relationships among American Mercenaria taxa by assessing variation in a 444 nucleotide fragment of the mitochondrial $16 \mathrm{~S}$ ribosomal gene in clams sampled from four representative sites in January to November 1994. Three of these sites were in the Gulf of Mexico, one was on the Atlantic coast in South Carolina. Direct sequencing of this amplified gene fragment in 85 individuals revealed 21 haplotypes. Phylogenetic analyses consistently resolved this variation into three well supported clades, and within-clade genetic divergence levels were markedly lower than among-clade values. One of the clades, A, was taxon-specific, in that it solely and exclusively contained specimens of $M$. mercenaria (Linnaeus, 1758) sampled in South Carolina. The other two clades, B and C, were the most divergent and both encompassed specimens of $M$. campechiensis (Gmelin, 1791) and of M. campechiensis texana (Dall, 1902), sampled from the three Gulf of Mexico sites. Clade $\mathrm{B}$ was found at high frequencies at all three Gulf sites, whereas Clade $\mathrm{C}$ occurred at low frequencies at two western Gulf sites. We interpret this pattern as resulting from the secondary contact and introgression of two allopatrically differentiated Mercenaria taxa in the western Gulf of Mexico. Clade C haplotypes may represent relict mitochondrial lineages from original Gulf Mercenaria spp. populations that predate massive mitochondrial introgression by $M$. campechiensis. We further propose that the $M$. campechiensis texana
\end{abstract}

Communicated by J. P. Grassle, New Brunswick

D. Ó Foighil - T. J. Hilbish · R. M. Showman Baruch Institute, University of South Carolina, Columbia, South Carolina 29208, USA

D. Ó Foighil (凶)

Museum of Zoology and Department of Biology,

University of Michigan, Ann Arbor,

Michigan 48109-1079, USA nuclear genome is a mosaic, heavily weighted toward $M$. campechiensis, but containing some relict alleles inherited from the precontact population, especially those governing shell characteristics, which may be adaptive in cohesive sediments of bays and estuaries in the northwestern Gulf of Mexico.

\section{Introduction}

Sibling species are by definition difficult or impossible to distinguish based on morphology (Mayr and Ashlock 1991) and are ubiquitous in the marine environment (Knowlton 1993). Their apparent prevalence among marine invertebrate taxa is due in part to a lack of systematic information, however, prominent among their ranks are members of well-studied genera, e.g., Mytilus (Seed 1992), Menippe (Bert and Harrison 1988), Echinometra (Lessios and Cunningham 1990) and Capitella (Grassle 1980). Morphological similarity among sibling species frequently masks significant levels of genetic divergence, in addition to differences in habitat, physiology, life history and degree of reproductive isolation (Knowlton 1993).

Despite the taxonomic difficulties posed by these taxa, they represent valuable model systems for investigating speciation processes in marine invertebrates, e.g., how recently derived, presently sympatric, sibling species evolved in taxa with high-dispersal pelagic larvae (Palumbi 1992). In some well-studied sibling species complexes investigation has focused on the underlying pre- or post-zygotic mechanisms of reproductive isolation operating in sympatry (reviewed by Knowlton 1993; Palumbi 1994). However, a prerequisite to such speciation studies is the construction of a phylogenetic framework encompassing the species of interest. The paucity of tractable morphological characters reduces the value of available fossil data and results in phylogenetic inferences being based primarily on estimates of genetic difference. A variety of genetic 
markers are available ranging from protein charge polymorphisms to nucleotide sequence variation in both nuclear and organellar genomes. These various approaches allow phylogenetic inferences to be made from different genetic perspectives and may therefore yield divergent results in some cases (reviewed by Avise 1994; Mitton 1994).

Two species of the venerid clam genus Mercenaria [M. mercenaria (Linnaeus, 1758); $M$. campechiensis (Gmelin, 1791)] occur on the east coast of North America. M. mercenaria has a primarily inshore distribution on the Atlantic coast, whereas $M$. campechiensis is present in the Gulf of Mexico and also in more offshore Atlantic locations as far north as New Jersey (Abbott 1974; Dillon and Manzi 1989a). Despite the broad range overlap, the two taxa are not often truly sympatric (Menzel 1989), but they hybridize to varying degrees of intensity wherever they co-occur (Dillon and Manzi 1989a; Dillon 1992; Bert et al. 1993; Bert and Arnold 1995). They can be distinguished on the basis of minor but fairly consistent morphological distinctions (Abbott 1974; Dillon and Manzi 1989a; Menzel 1989), allozymes (Dillon and Manzi 1989a; Bert et al. 1993); mitochondrial DNA restriction fragment length polymorphism (RFLP) (Brown and Wolfinbarger 1989), air exposure tolerance, salinity/temperature tolerance, and growth rates (Menzel 1989).

Systematic studies of American Mercenaria species are complicated by the presence of distinct regional morphological variation within Gulf of Mexico populations which has been variously interpreted by taxonomists. Eastern Gulf Floridian populations and southern Gulf Mexican populations exhibit typical $M$. campechiensis shell features, which include thick concentric ribbing that resists erosion (Dillon and Manzi 1989a). Northwestern Gulf populations of Mercenaria spp. along the Texas coast are morphometrically quite similar to $M$. campechiensis but differ conspicuously in shell sculpture (Dillon and Manzi 1989b). The Texas morphotype has thin concentric ribs that easily erode to yield a smooth shell surface, a general feature also found in $M$. mercenaria (Abbott 1954; Dillon and Manzi 1989b). Based primarily on differential weighting of shell characters the Texas morphotype has been variously classified as $M$. campechiensis texana (Dall, 1902), M. mercenaria texana (Abbott 1954), or as a natural hybrid of $M$. campechiensis and $M$. mercenaria (Menzel, 1970).

The problem in Mercenaria spp. taxonomy is therefore not due to an absence of morphological variation, but to the inferred systematic significance of this variation. Application of genetic markers to American Mercenaria taxa has provided new and somewhat contradictory insights into their phylogenetic relationships. Allozyme variation readily differentiates $M$. campechiensis from M. mercenaria (Dillon and Manzi 1989a; Bert et al. 1993; Bert and Arnold 1995) but populations of the Texas morphotype are allozymically very similar, if not indistinguishable, from $M$. campechiensis (Dillon and Manzi 1989b; T.M. Bert personal communication). On this basis Dillon and Manzi (1989b) proposed that the Texas morphotype be referred to as M.campechiensis texana and we adhere to this nomenclature. Mitochondrial RFLP analyses, however, detected "similar degrees of divergence between all three taxa" with indications that $M$. campechiensis texana may be of multiple maternal origin (Brown and Wolfinbarger 1989).

A major problem faced by Brown and Wolfinbarger (1989) was the high frequency of mtDNA length heteroplasmy, occurring in up to $89 \%$ of individuals in some populations sampled, thereby complicating the interpretation of restriction pattern polymorphisms. In the present study we performed a more detailed analysis of mitochondrial genome diversity among the three American Mercenaria taxa using direct sequencing of a PCR-amplified portion of the $16 \mathrm{~S}$ ribosomal RNA gene to avoid this difficulty. We included population samples of $M$. campechiensis from both the southern and eastern Gulf of Mexico, thereby bracketing the $M$. campechiensis texana region in the northwestern Gulf. Our aim was to obtain a higher resolution understanding of mitochondrial genome diversity among American Mercenaria taxa and to construct a phylogenetic framework that could encompass and integrate the discordant character sets presently available for this sibling species complex.

\section{Materials and methods}

Sources of specimens

All 85 North American specimens utilized in this study were adult clams ranging in valve length from 8 to $14 \mathrm{~cm}$. See Fig. 1 for the location of the four sampling sites. A total of 20 specimens of Mercenaria mercenaria (Linnaeus, 1758) were sampled in January 1994 from lower intertidal mudflats of the high-salinity ( 28 to $30 \%$ ) estuary at the Baruch Marine Laboratory, South Carolina. Twenty adult $M$. campechiensis (Gmelin, 1791) were obtained from shallow subtidal ( $<1 \mathrm{~m}$ depth) oyster shell hash substrate at Cedar Key (salinity typically $>30 \%$ ) on the Florida Gulf Coast in March 1994 (B. Arnold personal communication). These two sites represent central regions of the geographic ranges of the respective Mercenaria species, which have previously been characterized by allozyme surveys (Dillon and Manzi 1989a; T.M. Bert personal communication). An additional $14 M$. campechiensis were sampled from a southern Gulf of Mexico at Playa Ceiba, Campeche, Mexico in November 1994. A total of $31 \mathrm{M}$. campechiensis texana (Dall, 1902) were obtained from Port Aransas, Texas, in the northwestern Gulf of Mexico during April 1994. This population had previously been characterized allozymically (T.M. Bert unpublished) and, in the present study, the sample was taken from a subtidal (1 to $2 \mathrm{~m}$ depth) seagrass bed with a $10 \%$ silt clay fraction and a salinity average of $35 \%$ (K. Dunton personal communication). Finally, four specimens of the Asian congener, $M$. stimpsoni (Gould, 1861), were sampled from Wakkanai, northern Hokkaido, Japan to serve as an outgroup for phylogenetic analyses.

Dillion and Manzi $(1989 a, b)$ tested the efficacy of shell characteristics, including lunule shape, degree of ridging, nacre color and 


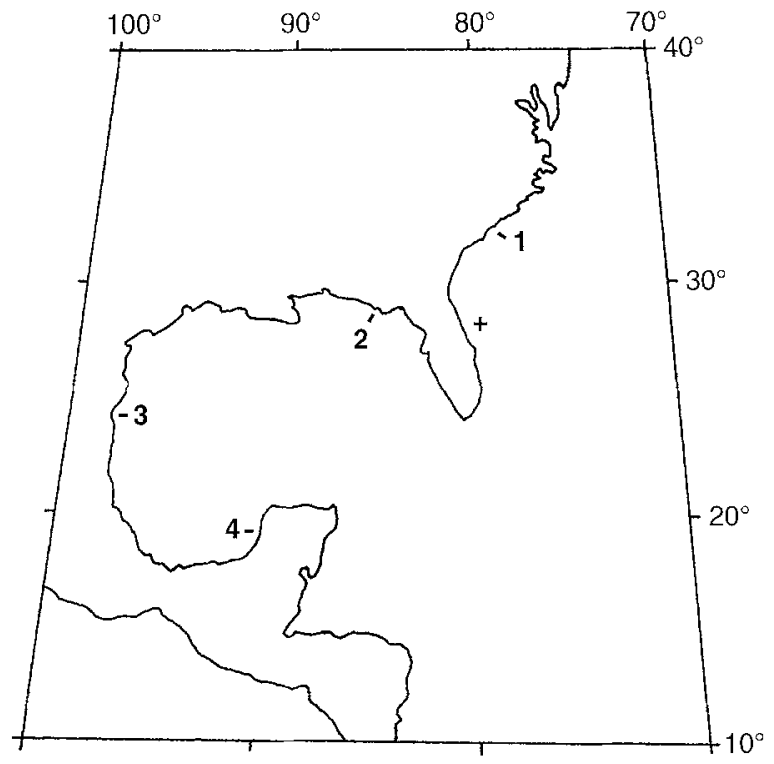

Fig. 1 Outline of the southeast coastline of North America $\left(70^{\circ}\right.$ to $100^{\circ} \mathrm{W} ; 10^{\circ}$ to $40^{\circ} \mathrm{N}$ ) showing sampling sites ( 1 Belle Baruch Marine Laboratory, South Carolina, USA; 2 Cedar Key, Florida, USA; 3 Port Aransas, Texas, USA; 4 Playa Ceiba, Campeche, Mexico; + Indian River, Florida, USA, a well-studied hybrid zone involving $M$. mercenaria and $M$. campechiensis, see "Discussion")

multivariate morphometric analyses of shell shape, to distinguish the various North American Mercenaria spp. They found shell ridging and nacre color to be good, but not absolute, predictors of taxonomic status, especially in distinguishing $M$. mercenaria from $M$. campechiensis. Based on their analyses, we attributed clams with thin ridges and purple nacre (South Carolina sample) to $M$. mercenaria, with thick external ridging and white nacre (Cedar Key and Campeche samples) to $M$. campechiensis, specimens and clams with thin ridges and white nacre (Port Aransas sample) to $M$. campechiensis texana. We are aware of the potential limitations of this approach, especially in the case of the Campeche sample, which comes from an electrophoretically uncharacterized portion of this species complexes' range (T.M. Bert personal communication).

\section{Extraction and amplification of DNA}

Samples from the three sites in the United States were received alive and tissue samples (visceral mass) were archived for future allozyme studies. Samples from Mexico and Japan had been preserved in $95 \%$ ethanol when received and tissue subsamples were rehydrated in distilled water prior to DNA extraction. DNA templates for thermal cycle amplification were prepared from individual clams by macerating approximately $50 \mathrm{mg}$ of mantle edge in $500 \mu \mathrm{l}$ of lysis buffer (0.1 $M$ Tris- $\mathrm{OH}, \mathrm{pH} 8.0,0.05 \mathrm{M}$ EDTA, $0.2 \mathrm{M} \mathrm{NaCl}, 1 \%$ SDS with 0.5 to $1 \mathrm{ml}$ proteinase $\mathrm{K}$ ) followed by incubation at $65^{\circ} \mathrm{C}$ for $2 \mathrm{~h}$. Digests were extracted twice with buffered phenol and once with chloroform/isoamyl alcohol (24:1). The DNA was then ethanol precipitated, dried and resuspended in $100 \mu \mathrm{l}$ of sterile water. Subsequently, $1 \mu 1$ of this template was used in a $25 \mu \mathrm{l}$ double-stranded PCR amplification mix employing "universal" $16 \mathrm{~S}$ mitochondrial rRNA primers: 16Sar 5'-CGCCTGTTTATCAAAAACAT-3'; 16Sbr 5'-CCGGTCTGAACTCAGATCACGT-3' (Kessing et al. 1989). A negative control (no template) was included in each run. After 35 cycles of amplification $\left(1 \mathrm{~min} 94^{\circ} \mathrm{C}\right.$ denaturing, $1 \mathrm{~min} 52^{\circ} \mathrm{C}$ annealing, $1 \mathrm{~min} 72^{\circ} \mathrm{C}$ extension), double stranded products approximately 510 nucleotides in length were isolated on $1 \%$ agarost: gels, excised under long wavelength UV light and extracted using a GeneClean (Bio 101) NaI/glass powder kit.

\section{Sequencing}

Aliquots of the amplified fragments were sequenced directly using one of the original amplification primers (16Sbr) and an internal sequencing primer: 5'-GTTAATATTGCCCCA-3'. A modified Sequenase (United States Biochemical) protocol was employed in which the annealing mix was denatured at $99^{\circ} \mathrm{C}$ for $2 \mathrm{~min}$ in the presence of $10 \%$ DMSO, immediately snap-frozen in a $-80^{\circ} \mathrm{C}$ prechilled block and allowed to anneal while thawing at room temperature. All samples were sequenced manually and alignments and restriction site identifications were respectively determined using the BEST-FIT and MAP algorithms of Wisconsin Package 7.3 (Genetics Computer Group Inc.). A matrix of DNA sequence divergence among the taxa was produced with the Distance program of MEGA 1.01 (Kumar et al. 1993) using Jukes-Cantor's correction. Phylogenetic trees were constructed using the MEGA 1.01 neighbor-joining analysis (Kumar et al. 1993) and the DNABOOT maximum parsimony method (Felsenstein 1990). Bootstrapping (Felsenstein 1990) was used to assess support levels for clades in both types of phylogenetic analyses. Alternative tree topologies were assessed using the DNA maximum likelihood test (Felsenstein 1990).

Diagnostic endonuclease restriction digests were performed on the amplified 16S gene fragments from the Port Aransas specimens using Dra I (5'-TTTAAA-3') according to the manufacturer's instructions (New England Biolabs). Digestion products were electrophoresed on $2 \%$ agarose gels, stained with ethidium bromide and visualized by UV transillumination.

\section{Results}

The complete 444 nucleotide sequence determined for the amplified $16 \mathrm{~S}$ mtRNA gene fragment of a South Carolina Mercenaria mercenaria specimen is shown in Fig. 2. Nucleotide sequence variation assayed in amplified homologous fragments of this gene for the other 88 Mercenaria spp. individuals is summarized in Fig. 3. A total of 22 unique sequences (haplotypes) were observed, 21 of these in the North American samples. For the total data set, including the Japanese outgroup, $M$. stimpsoni, 60 variable positions were detected, 21 of

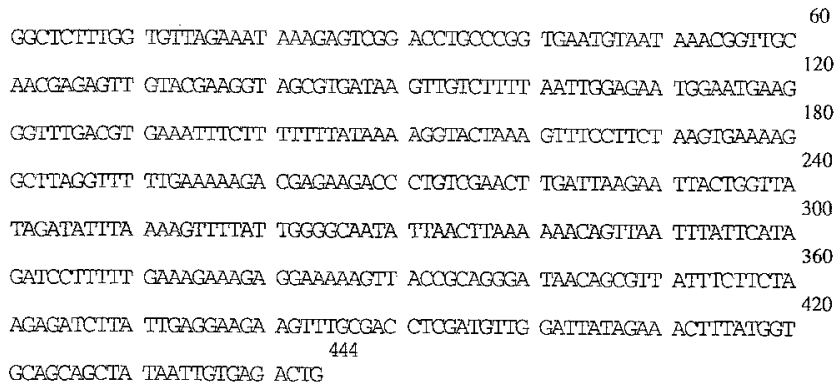

Fig. 2 Mercenaria mercenaria. DNA sequence of an amplified 16S mtRNA gene fragment from a South Carolina specimen (Haplotype SC1). The 444 nucleotide positions shown here were also determined for the amplified homologous gene fragment from 88 additional Mercenaria spp. specimens utilized in present study 


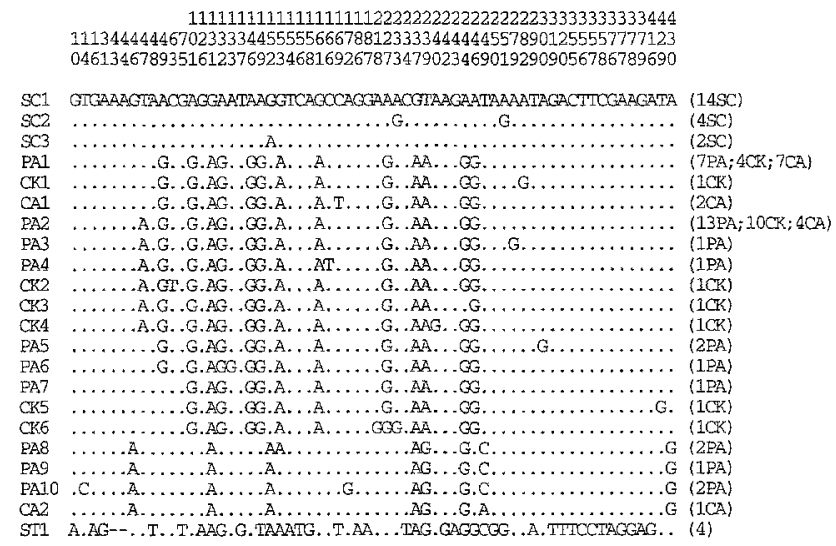

Fig. 3 Mercenaria spp. Alignment of the 60 homologous variable positions in the $16 \mathrm{~S}$ mtRNA gene fragment sequenced for 21 North American haplotypes together with a Japanese outgroup (STI). Positions of each variable site within the amplified 444 nucleotide $\mathrm{Mer}$ cenaria spp. 16S gene fragment are presented vertically above the nucleotide columns. See Fig. 2 for complete fragment sequence for the first haplotype, $\mathrm{SC} 1 . S C, C K, P A$ and $C A$ indicate haplotypes first encountered in South Carolina, Cedar Key, Port Aransas and Campeche clams, respectively; dots indicate nucleotide identity to the first sequence presented, $\mathrm{SC1}$, and inferred changes relative to $\mathrm{SCl}$ are shown with insertion/deletion events indicated by dashes. Number of individuals per haplotype for each sample indicated in parentheses at the end of each sequence

these being informative under the parsimony criterion. When North American samples alone were considered, 19 of 31 variable sites were phylogenetically informative.

Both distance and parsimony analyses consistently resolved the North American data set into three clades and yielded essentially the same tree topologies (Fig. 4). Within-clade genetic divergence levels are markedly lower than among-clade values (Table 1 ) and the nodes leading to each clade are supported by relatively robust bootstrap estimates (Fig. 4). One of the clades, A, is taxon-specific in that it solely and exclusively contains specimens of Mercenaria mercenaria sampled in South
Carolina. The other two clades, B and $\mathrm{C}$, both contain specimens of $M$. campechiensis and of $M$. campechiensis texana, all sampled from Gulf of Mexico sites. Their distribution, however, among the Gulf samples was not uniform (Table 2). The eastern Gulf $M$. campechiensis sample from Cedar Key, Florida was composed solely of Clade B haplotypes. This is the largest of the three clades, containing 14 haplotypes and the greatest within-clade variation $(0.23$ to $1.16 \%)$. The two most common Clade B haplotypes, PA1 and PA2, were prevalent in all three Gulf samples (Fig. 3), jointly composing 70, 77 and $78 \%$, respectively, of the Cedar Key, Port Aransas, and Campeche samples.

Relatively few Clade $\mathrm{C}$ haplotypes were detected in the Port Aransas and Campeche samples (Table 2). One surprising result is that Clades $B$ and $C$, which co-occur in similar ratios in these western Gulf samples of both $M$. campechiensis and $M$. campechiensis texana (Table 2), show the highest degree of genetic divergence (3.04 to $4.25 \%$ ) among the three North American $\mathrm{Mer}$ cenaria spp. clades (Table 1). This is reflected in the inferred phylogenetic trees where Clades $\mathrm{A}$ and $\mathrm{C}$ consistently group together, although the common $\mathrm{A} / \mathrm{C}$ node is supported less strongly by bootstrapping than those nodes leading to each individual clade (Fig. 4). Alternative branching orders of the three clades were analyzed using the DNA maximum likelihood test

Fig. 4 Mercenaria spp. Phylogenetic tree obtained from mitochondrial lineages by neighbor joining analysis with bootstrapping ( 500 iterations). The Japanese congener $M$. stimpsoni ( $S T I$ ) was used as an outgroup. Maximum parsimony analyses with bootstrapping yielded essentially the same topology with only minor intraclade rearrangement of some terminal tips. Bootstrap estimates shown only for major nodes that were supported at levels $>50 \%$. Above branches values from neighbor-joining analysis; below branches values from separate maximum parsimony analysis. $S C, C K, P A$ and $C A$ indicate haplotypes first encountered in South Carolina, Cedar Key, Port Aransas and Campeche, respectively. See Fig. 3 for haplotype identification. With the exception of PA1 and PA2, each haplotype was restricted to the sampling site indicated by the given prefix. Number of individuals per haplotype in parentheses

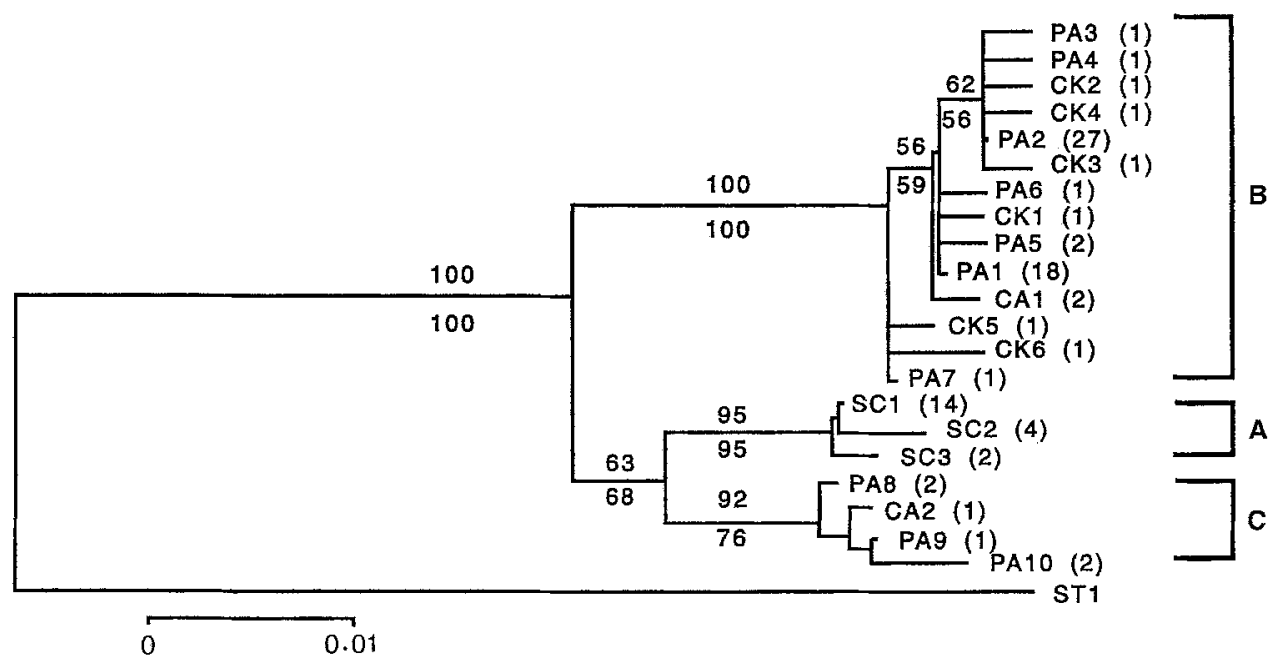


Table 1 Mercenaria spp. Mean percent genetic divergence values (p-distances) with standard errors within and among North American clades and the outgroup $M$. stimpsoni. Values calculated using MEGA 1.01 (Kumar et al. 1993)

\begin{tabular}{llll}
\hline & Clade A & Clade B & Clade C \\
\hline Clade A & $0.47 \pm 0.15$ & & \\
Clade B & $3.39 \pm 0.05$ & $0.64 \pm 0.03$ & \\
Clade C & $2.08 \pm 0.10$ & $3.56 \pm 0.06$ & $0.47 \pm 0.73$ \\
M. stimpsoni & $9.03 \pm 0.07$ & $9.07 \pm 0.09$ & $8.33 \pm 0.14$ \\
\hline
\end{tabular}

Table 2 Mercenaria spp. Mitochondrial clade distribution among the four North American sites. Number of haplotypes present per clade is shown with total number of individuals per clade in parentheses ( - no haplotypes found)

\begin{tabular}{llll}
\hline Site & Clade A & Clade B & Clade C \\
Species & & & \\
\hline $\begin{array}{l}\text { South Carolina } \\
\text { M. mercenaria }\end{array}$ & $3(20)$ & - & - \\
$\begin{array}{l}\text { Cedar Key } \\
\quad \text { M. campechiensis }\end{array}$ & - & $8(20)$ & - \\
$\begin{array}{l}\text { Port Aransas } \\
\text { M. campechiensis texana }\end{array}$ & - & $7(26)$ & $3(5)$ \\
$\begin{array}{l}\text { Campeche } \\
\text { M. campechiensis }\end{array}$ & - & $3(13)$ & $1(1)$ \\
\hline
\end{tabular}

(Felsenstein 1990) and the $[\mathrm{B},(\mathrm{A}, \mathrm{C})]$ topology shown in Fig. 4 yielded the best score.

No evidence for intragenic heteroplasmy in the amplified $16 \mathrm{~S}$ gene fragment was evident in the direct sequences obtained from any of the 85 North American Mercenaria spp. specimens assayed during this study. Using RFLP analysis of the amplified gene fragment, Port Aransas samples were additionally checked for potential $16 \mathrm{~S}$ intragenic heteroplasmy involving the two mitochondrial clades (B, C) which co-occur in this population. Constituent haplotypes of these clades encountered in the Port Aransas sample differ in their Dra I digestion products due to a transition substitution at Position 249 (Fig. 3). No evidence for a B/C hetroplasmic condition was detected in any of the Port Aransas specimens.

\section{Discussion}

Phylogenetic analyses consistently resolved mitochondrial 16S ribosomal gene variation in American Mercenaria sibling species into three distinct clades. Some aspects of the biogeographic and systematic distribution patterns of these clades are congruent with previous morphological and allozyme data. This is most apparent with $M$. mercenaria and $M$. campechiensis, which appear distinct whether morphological (Abbott
1974; Dillon and Manzi 1989a; Menzel 1989), allozyme (Dillon and Manzi 1989a; Bert et al. 1993) or mitochondrial DNA (Brown and Wolfinbarger 1989; present study) characters are assayed.

Multiple character congruency however breaks down into complex subpatterns when the phylogeographic relationships among the Gulf of Mexico samples, and especially of Mercenaria campechiensis texana, are considered. The presence of two highly diverged mitochondrial clades within western Gulf Mercenaria spp. populations is not completely concordant with the distribution of either morphological (Abbott 1974; Dillon and Manzi 1989b) or allozyme (Dillon and Manzi 1989b; T.M. Bert personal communication) markers. Rather we find two distinct clades in these populations, which show phylogenetic ties to haplotypes found in either $M$. campechiensis or $M$. mercenaria.

Various evolutionary processes have been proposed to account for the co-existence of highly divergent mitochondrial clades within natural populations. These include the possibility that the polymorphism results from: (1) doubly uniparental inheritance of mitochondria; (2) cryptic species; (3) retention of ancestral polymorphisms; and (4) secondary contact between genetically distinct populations.

An intriguing phenomenon recently discovered in blue mussels (Mytilus spp.) is that of doubly uniparental inheritance of sex-linked mitochondrial lineages (Hoeh et al. 1991; Skibinski et al. 1994; Zouros et al. $1994 a, b)$. There are two lines of evidence suggesting that the mtDNA polymorphism observed in western Gulf Mercenaria spp. populations is not due to doubly uniparental inheritance. First, a key feature of the doubly uniparental Mytilus spp. mitochondrial system is that male-specific lineages occur only in conditions of heteroplasmy (Skibinski et al. 1994; Zouros et al. 1994a, b). We have no evidence for intragenic heteroplasmy in any of the Mercenaria spp. specimens assayed in this study, including the western Gulf of Mexico samples. Second, this phenomenon would likely occur in all three sibling Mercenaria taxa because the co-occurring divergent mitochondrial clades have common ancestors in either M. campechiensis or M.mercenaria. However, this mtDNA polymorphism appears to be absent from reference populations of $M$. campechiensis in the eastern Gulf of Mexico and from Atlantic coast populations of $M$. mercenaria and $M$. campechiensis (Brown and Wolfinbarger 1989; present study; Ó Foighil unpublished). Therefore, we conclude that a doubly uniparental mitochondrial inheritance system is an unlikely explanation for the mtDNA polymorphism observed in western Gulf Mercenaria spp. populations.

A second possibility is the presence in the western Gulf of reproductively isolated cryptic species with different mtDNA lineages. However, the absence of significant allozymic dichotomy (Dillon and Manzi 
1989b; T.M. Bert personal communication) in populations of $M$. campechiensis texana does not support the presence of cryptic species.

The third possibility is that the pronounced mtDNA polymorphism in the western Gulf of Mexico results from the long-term persistence of ancestral population polymorphisms coupled with the stochastic extinction of mitochondrial lineages (Neigel and Avise 1986; Ball et al. 1990). In principle, this process should result in the presence of highly divergent clades throughout a species' geographic range and the occurrence of many lineages of intermediate levels of divergence within each clade. We are not aware of pertinent examples in marine taxa, but Georgiadis et al. (1994) document such a pattern of mtDNA diversity in Loxodonta africana, the African elephant. The Mercenaria spp. data do not conform to the expected patterns of mtDNA diversity predicted by this hypothesis. Clade B haplotypes were found at all three sites in the Gulf of Mexico (Brown and Wolfinbarger 1989; present study) and also occurred in clams from the Indian River on the Atlantic coast of Florida (Ó Foighil unpublished). Clade C haplotypes appear to be restricted to the western Gulf of Mexico (Brown and Wolfinbarger 1989; present study; Ó Foighil unpublished). Intraclade genetic divergence levels in Clades B and C are much less than interclade values and intermediate haplotypes are conspicuously absent.

The observed geographic distribution and genetic divergence patterns of the mtDNA clades of Mercenaria spp. from the Gulf of Mexico do, however, conform to the predictions of the fourth hypothesis: that of mitochondrial introgression in a region of secondary contact between two allopatrically differentiated taxa (Avise et al. 1987). This hypothesis predicts that divergent haplotypes co-occur only within limited subsections of a taxon's geographic range and that intermediate haplotypes are absent (Solignac and Monnerot 1986; Lehman et al. 1991; Wayne and Jenks 1991; Zink 1994). This is essentially what we observe in the Mercenaria spp. mtDNA data and we therefore propose that the western Gulf of Mexico represents a zone of secondary contact and introgression between two genetically differentiated Mercenaria spp. taxa. The geographic extent of the hypothesized zone of secondary contact is, however, unclear and it is possible that it was once much smaller than the present day distribution attained by Clade $\mathrm{C}$ haplotypes.

Brown and Wolfinbarger (1989) used RFLP analysis to examine mtDNA variation in Mercenaria spp., including samples from the Gulf of Mexico. Their results are largely consistent with ours in that they observed significant mtDNA differentiation among $M$. mercenaria and $M$. campechiensis and that $M$. campechiensis texana populations contained two clades, each with phylogenetic ties to one of the other congeners. Our results differ significantly from those of Brown and Wolfinbarger (1989) in that we do find shared haplotypes at high frequencies among $M$. campechiensis and $M$. campechiensis texana, indicating recent large scale gene flow between these two taxa. Our interpretation of the mtDNA data also differs from that of Brown and Wolfinbarger (1989). They did not consider $M$. campechiensis texana to be of hybrid origin and pooled the divergent haplotypes present in this taxon to estimate that all three Mercenaria taxa have similar degrees of mitochondrial genetic divergence. We consider that the available data are more consistent with the hypothesis of secondary contact between two genetically differentiated Mercenaria spp. taxa and that pooling the divergent haplotypes obscures their underlying phylogenetic relationships.

In cases of ongoing or recent organellar genome introgression the sources of the divergent haplotypes can frequently be identified with some certainty (Solignac and Monnerot 1986; Lehman et al. 1991; Wayne and Jenks 1991; Zink 1994). If the mitochondrial dichotomy in western Gulf of Mexico Mercenaria spp. populations is indeed the result of secondary contact, then $M$. campechiensis is evidently the major source of recent organellar genome flow into these populations. This conclusion is based on the predominance of two individual Clade B haplotypes throughout the Gulf of Mexico and the apparent exclusivity of Clade B in eastern Gulf populations (Brown and Wolfinbarger 1989; present study), which have been used as M. campechiensis reference populations for allozymic and shell morphology analyses (Dillon and Manzi 1989b).

Of the three Mercenaria spp. mitochondrial clades encountered in this study Clade $\mathrm{C}$ is the most enigmatic in origin. It appears restricted to the western Gulf of Mexico putative secondary contact zone where it occurs in relatively low frequencies in $M$. campechiensis texana (Brown and Wolfinbarger 1989; present study) and also in specimens of $M$. campechiensis from Mexico. Although Clade A and $\mathrm{C}$ haplotypes consistently clustered together in phylogenetic trees, the relatively low support for this node precludes the positive identification of Clade $\mathrm{A}$ and $\mathrm{C}$ as a monophyletic grouping. Assaying a faster evolving mitochondrial gene for these taxa would yield more phylogenetically informative sites and could satisfactorily resolve this issue.

Clade $\mathrm{C}$ haplotypes may represent relict mitochondrial lineages from original Gulf of Mexico Mercenaria spp. populations that predate secondary contact and massive mitochondrial introgression by $M$. campechiensis. This condition is not without precedent in hybrid taxa where, in some cases, not all of the organellar genome source species are identifiable and some may have subsequently become extinct, leaving surviving haplotypes only in the hybrid populations (Wang and Szmidt 1994). How then can the hypothesized relict secondary contact zone in western Gulf of Mexico Mercenaria spp. populations be integrated with the 
known distribution of allozyme and morphological markers within Gulf populations?

Allozymic variation in Gulf of Mexico Mercenaria spp. populations consists of a unimodal distribution of M. campechiensis alleles with no evidence for significant dichotomy among or within populations, including the Port Aransas population (Dillon and Manzi 1989b; T.M. Bert personal communication). This partially agrees with the mitochondrial results, which are also dominated by the $M$. campechiensis clade (B), however, it is not congruent with the minority presence of the highly divergent Clade $\mathrm{C}$ haplotypes in western Gulf populations. DNA-based techniques are more sensitive than allozymes and may detect marked genetic differentiation (nucleotides) among recently diverged taxa which are still allozymically (charged amino acids) uniform (Buroker 1983; Reeb and Avise 1990; Karl and Avise 1992). However, significant allozymic differentiation is evident between $M$. mercenaria and M. campechiensis (Dillon and Manzi 1989a; Bert et al. 1993; Bert and Arnold 1995), which show lower levels of mitochondrial divergence (Clades A, C; Table 1) than do the two co-occurring western Gulf clades $(B, C$; Table 1). It is reasonable to conclude, therefore, that if the mitochondrial dichotomy is matched by similar levels of nuclear genome differentiation within western Gulf populations, it should be detectable allozymically. Why is this not the case?

Results from a well studied hybrid zone of Mercenaria mercenaria and $M$. campechiensis in the Indian River (Dillon and Manzi 1989a; Bert et al. 1993; Bert and Arnold 1995) are relevant to this question. Selection against hybrids is clearly evident in this zone and seems to act principally against $M$. mercenaria alleles and, to a lesser degree, in favor of $M$. campechiensis backcrosses (Bert et al. 1993; Bert and Arnold 1995). Both western Gulf populations we investigated were predominantly composed $(26: 5 ; 13: 1)$ of Clade B (M. campechiensis) haplotypes, and Brown and Wolfinbarger (1989) reported similar results for their Port Aransas sample (24:5). These ratios of mitochondrial Clades B and C may generally correspond to the relative nuclear genome contributions made by the hybridizing taxa at the initiation of the putative secondary contact zone, i.e., predominantly $M$. campechiensis. Selection on the genetic linkage groups containing allozyme loci that acted against hybrid recombinants, or in favor of numerically dominant $M$. campechiensis alleles, could result in the fixation of $M$. campechiensis alleles at these loci. Mitochondria, however, do not recombine (Brown 1985) and in the apparent absence of significant negative cytonuclear interaction there is no obvious barrier to the long term persistence of the Clade C relict haplotypes in a primarily $M$. campechiensis nuclear genome milieu.

Although the allozyme data are consistent with the hypothesis that Mercenaria campechiensis texana has a purely $M$. campechiensis nuclear genome, we consider this to be unlikely. Both taxa can be distinguished by external shell sculpture characteristics: prominent thick concentric ridging that resists erosion on $M$. campechiensis shells and thin, easily eroded concentric ridging on $M$. campechiensis texana (Abbott 1954; Dillon and Manzi 1989b). This shell character in Mercenaria spp. is primarily, if not completely, under genetic control and $\mathrm{F}_{1}$ hybrids of $M$. mercenaria and $M$. campechiensis show intermediate degrees of ridge development independent of environmental influence (Dillon and Manzi 1989b). How has M. campechiensis texana apparently maintained a fixed, genetically based, distinct shell phenotype in the face of a massive influx of $M$. campechiensis genes?

Dillon and Manzi (1989b) proposed that the thin easily eroded ridging on $M$. campechiensis texana shells is an adaptation for enhanced burrowing ability in terrigenous mud and that the thick resistant ridging characteristic of $M$. campechiensis is a corresponding adaptation to life in coarser carbonate sediments. Support for this view is found in the coincident distribution of shell sculpture pattern (Dillon and Manzi 1989a) and sediment type (Rezak et al. 1990) within the Gulf of Mexico and also in the known adaptive significance of external shell sculpture patterns in soft-bottom infaunal bivalves (Seed 1980; Stanley 1981; Vermeij and Dudley 1985; Vermeij 1987). The prominent symmetrical concentric sculpturing characteristic of $M$. campechiensis may enable it to ameliorate significant scouring effects on the non-cohesive carbonate substrates of the southern and eastern Gulf continental shelfs (Rezak et al. 1990) without seriously compromising its digging ability. In the highly terrigenous sediments of the northwestern Gulf of Mexico (Rezak et al. 1990) the cost-to-benefit ratio of prominent symmetrical concentric sculpturing is likely to be reversed due to much greater sediment cohesion (Brown et al. 1989).

Arnold et al. (1996) find evidence for environmentally mediated selection in the Indian River Mercenaria mercenaria/M. campechiensis hybrid system where the two species, and their hybrids, have an advantage in specific habitats. We consider it plausible that in the putative Mercenaria spp. secondary contact zone of the western Gulf of Mexico some nuclear genes from the precontact population have persisted and that relict alleles that confer a significant habitat-specific selective advantage over $M$. campechiensis homologues, such as those controlling shell sculpture in the northwestern Gulf, have become fixed. We propose that the $M$. campechiensis texana nuclear genome is a mosaic, heavily weighted toward $M$. campechiensis, but containing a sprinkling of relict genes inherited from the precontact population, especially those yielding a selective advantage in the distinct environmental conditions of the northwestern Gulf (Rezak et al. 1990). Although divergent Clade $\mathrm{C}$ haplotypes are also present in the southwestern Gulf Campeche population of $M$. campechiensis, lack of selective pressure for smoother 
shells in this non-cohesive carbonate sediment area may impede the co-introgression of relict $M$. campechiensis texana nuclear genes that code for this phenotype.

A remarkable feature of American Mercenaria sibling species is that character sets that yield congruent distinctions among some constituent taxa (M. mercenaria and $M$. campechiensis) give very discordant results when applied to others. Indeed among Gulf of Mexico Mercenaria spp. populations separate consideration of morphological, allozyme and mitochondrial character sets would result in three distinct and contradictory conclusions concerning the phylogeographic relationships of these populations. The non-recombinant mitochondrial haplotypes are key to interpreting this mélange because they retain the dichotomous phylogenetic signal, lost by the nuclear coded allozyme and shell morphology phenotypes, that western Gulf populations of Mercenaria spp. straddle a relict zone of secondary contact.

Acknowledgements We are indebted to a number of colleagues for kindly sending us samples for this study: H. Honma and J.M. Oishi for Hokkaido specimens of $M$. stimpsoni; M. Reguero Reza, A. Navarrete del Proo and M. Medina for Mexican samples of $M$. campechiensis; B. Arnold and T. Bert for Cedar Key samples of $M$. campechiensis; K. Dunton for Port Aransas samples of $M$. campechiensis texana. Our thanks to $\mathrm{T}$. Bert for communicating unpublished results on Gulf of Mexico Mercenaria spp. allozyme variation, to J. Quattro for help with DNAML analysis, and to $M$. Liu and D. Vogt for help with the figures. We thank D. Heath, T. Bert, and two anonymous reviewers for their comments on manuscript drafts. This work was supported by the South Carolina Sea Grant Consortium and the National Science Foundation (OCE9203320).

\section{References}

Abbott RT (1954) American seashells, 1st edn. Van Nostrand, Princeton

Abbott RT (1974) American seashells, 2nd edn. Van Nostrand Reinhold, New York

Arnold WS, Bert TM, Marelli DC, Cruz-Lopez H, Gill PA (1996) Genotype-specific growth of hard clams (genus Mercenaria) in a hybrid zone: variation among habitats. Mar Biol 125: 129-139

Avise JC (1994) Molecular makers, natural history and evolution. Chapman and Hall, New York

Avise JC, Arnold J, Ball RM (1987) Intraspecific phylogeography: the mitochondrial DNA bridge between population genetics and systematics. A Rev Ecol Syst 18: 489-522

Ball RM, Neigel JE, Avise JC (1990) Gene genealogies within the organismal pedigrees of random-mating populations. Evolution 44: $360-370$

Bert TM, Arnold WS (1995) An empirical test of predictions of two competing models for the maintenance and fate of hybrid zones: both models are supported in a hard clam hybrid zone. Evolution 49: 276-289

Bert TM, Harrison RG (1988) Hybridization in western Atlantic stone crabs (genus Menippe): evolutionary history and ecological context influence species interactions. Evolution 42: 528-544

Bert TM, Hesselman DM, Arnold WS, Moore WS, Cruz-Lopez H, Marelli DC (1993) High frequency of gonadal neoplasia in a hard clam (Mercenaria spp.) hybrid zone. Mar Biol 117: 97-104
Brown BL, Wolfinbarger L (1989) Mitochondrial restriction enzyme screening and phylogenetic relatedness in the hard shell clam genus Mercenaria. Part II. Population variation. Report VSG89-02. Virginia Sea Grant, Richmond, Va

Brown J, Colling A, Park D, Phillips J, Rothery D, Wright J (1989) Waves, tides and shallow-water processes. Pergamon Press, Oxford

Brown WM (1985) The mitochondrial genome of animals. In: MacIntyre RJ (ed) Evolutionary genetics. Plenum Press, New York pp 95-130

Buroker NE (1983) Population genetics of the American oyster Crassostrea virginica along the Atlantic coast and the Gulf of Mexico. Mar Biol 75: 99-112

Dillon RT (1992) Minimal hybridization between populations of the hard clams, Mercenaria mercenaria and Mercenaria campechiensis, co-occurring in South Carolina. Bull mar Sci 50: $411-416$

Dillon RT, Manzi JJ (1989a) Genetics and shell morphology in a hybrid zone between the hard clams Mercenaria mercenaria and $M$. campechiensis. Mar Biol 100: 217-222

Dillon RT, Manzi JJ (1989b) Genetics and shell morphology of hard clams (genus Mercenaria) from the Laguna Madre, Texas. Nautilus 103: 73-77

Felsenstein J (1990) Phylogeny inference package (PHYLIP) 3.4 University of Washington, Seattle

Georgiadis N, Bischof L, Templeton A, Patton J, Karesh W, Western D (1994) Structure and history of African elephant populations. 1. Eastern and southern Africa. J Hered 85: 100-104

Grassle JP (1980) Polychaete sibling species. In: Brinkhurst RO, Cook DG (eds) Aquatic oligochaete biology. Plenum Press, New York, pp 25-32

Hoeh WR, Blakley KH, Brown WM (1991) Heteroplasmy suggests limited biparental inheritance of Mytilus mitochondrial DNA. Science, NY 251: 1488-1490

Karl SA, Avise JC (1992) Balancing selection at allozyme loci in oysters: implications from nuclear RFLPs. Science, NY 256: $100-102$

Kessing B, Croom H, Martin A, McIntosh C, McMillan WO, Palumbi S (1989) The simple fool's guide to PCR. Version 1.0. University of Hawaii, Honolulu

Knowlton N (1993) Sibling species in the sea. A Rev Ecol Syst 24 $189-216$

Kumar S, Tamura K, Nei M (1993) MEGA: molecular evolutionary genetics analysis. Version 1.01. Pennsylvania State University, University Park, $\mathrm{Pa}$

Lehman N, Eisenhawer A, Hansen K, Mech LD, Peterson RO (1991) Introgression of coyote mitochondrial DNA into sympatric North American gray wolf populations. Evolution 45: $104-119$

Lessios HA, Cunningham CW (1990) Gametic incompatibility between species of the sea urchin Echinometra on the two sides of the Isthmus of Panama. Evolution 44: 933-941

Mayr E, Ashlock PD (1991) Principles of systematic zoology, 2nd edn. McGraw-Hill, New York

Menzel RW (1989) The biology, fishery and culture of quahog clams, Mercenaria. In: Manzi JJ, Castagna M (eds) Clam mariculture in North America. Elsevier, Amsterdam, pp 201-242

Mitton JB (1994) Molecular approaches to population biology. A Rev Ecol Syst 25: 45-69

Neigel JE, Avise JC (1986) Phylogenetic relationships of mitochondrial DNA under various demographic models of speciation. In: Nevo E, Karlin S (eds) Evolutionary processes and theory. Academic Press, New York, pp 515-534

Palumbi SR (1992) Marine speciation on a small planet. Trends Ecol Evolut 7: 114-118

Palumbi SR (1994) Genetic divergence, reproductive isolation, and marine speciation. A Rev Ecol Syst 25: 547-572

Reeb CA, Avise JC (1990) A genetic discontinuity in a continuously distributed species: mitochondrial DNA in the American oyster, Crassostrea virginica. Genetics, Baltimore, Md 124: 397-406 
Rezak R, Gittings SR, Bright TJ (1990) Biotic assemblages and ecological controls on reefs and banks of the northwest Gulf of Mexico. Am Zool 30: 23-35

Seed R (1980) Shell growth and form in the Bivalvia. In: Rhoads DC, Lutz RA (eds) Skeletal growth of aquatic organisms. Plenum Press, New York, pp 23-68

Seed R (1992) Systematics, evolution and distribution of mussels belonging to the genus Mytilus: an overview. Am malac Bull 9: 123-137

Skibinski DOF, Gallagher C, Benyon CM (1994) Mitochondrial DNA inheritance. Nature, Lond 368: 817-818

Solignac M, Monnerot M (1986) Race formation, speciation, and introgression within Drosophila simulans, D. mauritania and $D$. sechellia inferred from mitochondrial DNA analysis. Evolution 40: $531-539$

Stanley SM (1981) Infaunal survival: alternate functions of shell ornamentation in the Bivalvia (Mollusca). Paleobiology 7: 384-393

Vermeij GJ (1987) Evolution and escalation: an ecological history of life. Princeton University Press, Princeton, p 519
Vermeij GJ, Dudley EC (1985) Distribution of adaptations: a comparison between the functional shell morphology of freshwater and marine pelecypods. In: Trueman ER, Clarke MR (eds) The Mollusca. Vol. 10. Evolution. Academic Press, New York, pp 461-478

Wang XR, Szmidt AE (1994) Hybidization and chloroplast DNA variation in a Pinus species complex from Asia. Evolution 48: $1020-1031$

Wayne RK, Jenks SM (1991) Mitochondrial DNA analysis implying extensive hybridization of the endangered red wolf Canis rufus. Nature, Lond 351: 565-568

Zink RM (1994) The geography of mitochondrial DNA variation, population structure, hybridization, and species limits in the fox sparrow (Passerella iliaca). Evolution 48: 96-111

Zouros E, Ball AO, Saaverda C, Freeman KR (1994a) An unusual type of mitochondrial DNA inheritance in the blue mussel Mytilus. Proc natn Acad Sci USA 91: 7463-7467

Zouros E, Ball AO, Saaverda C, Freeman KR (1994b) Mitochondrial DNA inheritance. Nature, Lond 368: p 818 